Research Notes

\title{
Gastrointestinal Parasites of Cattle in Central Java
}

\author{
${ }^{1}$ Penny Humaidah Hamid, ${ }^{2}$ Yuli Purwandari Kristianingrum, \\ ${ }^{1}$ Joko Prastowo and ${ }^{3}$ Liliana Machado Ribeiro da Silva \\ ${ }^{I}$ Department of Parasitology, Veterinary Medicine, Universitas Gadjah Mada, Yogyakarta, Indonesia \\ ${ }^{2}$ Department of Pathology, Veterinary Medicine, Universitas Gadjah Mada, Yogyakarta, Indonesia \\ ${ }^{3}$ Institute of Parasitology, Justus Liebig University Giessen, Giessen, Germany
}

\author{
Article history \\ Received: 30-08-2016 \\ Revised: $13-10-2016$ \\ Accepted: 15-10-2016 \\ Corresponding Author: \\ Penny Humaidah Hamid \\ Department of Parasitology, \\ Veterinary Medicine, Gadjah \\ Mada University, J1. Fauna No \\ 2. Karangmalang, Yogyakarta \\ Indonesia \\ $\mathrm{Ph}:+62274560861$ \\ Fax: +62 274560861 \\ Email: penny_hamid@ugm.ac.id
}

\begin{abstract}
Gastrointestinal parasites are the main cause of losses of cattle farms including feed conversion-failure and even death of heavily infected animals. We have conducted a random examination of 455 cows in the Special Region of Yogyakarta-Central Java from March to June 2016. The examined animals were Ongole and Local Cattle (PO) cross breed, Simmental breed, Limousin breed, Simmental and PO cross breed, PO and Limousin cross breed, Friesian Holstein breed (FH), Brahman breed, Angus breed, Angus and Brahman cross breed and Bali breed. McMaster technique, saturated $\mathrm{NaCl}$ flotation technique and Parfitt and Banks technique were used simultaneously in this study in order to identify the parasitic stages present in the coprological samples. The test results showed that approximately $65.93 \%$ of the cattle population was infected by parasitic stages, such as: Strongylidae (54.00\%), Fasciola sp. (17.00\%), Eimeria spp. (15.33\%), Strongyloides sp. (4.67\%), Paramphistomum sp. (4.00\%), Trichuris sp. (3.67\%) and Moniezia sp. (1.33\%). Six different Eimeria species were identified: E. bovis, E. auburnensis, E. bukidnonensis, E. canadaensis, E. zurnii and E. cylindrica. Most of the animals presented monoinfections (79.33\%), but concomitant infections were also observed (2 different parasites: $17.67 \%$; 3 different parasites: $2.33 \%$; more than 3 different parasites: $0.67 \%$ ). With this work we proved the high level of parasitism in cattle of Central Java and we intensively highlight the need to find adequate control measures against parasitic diseases in order to reduce the detrimental impact of parasitosis in cattle.
\end{abstract}

Keywords: Parasites, Gastrointestinal, Cattle, Central Java

\section{Introduction}

Gastrointestinal parasitic diseases are the major cause of economic losses in domestic animals worldwide (Corwin, 1997; McLeod, 1995; Grisi et al., 2014; Bandyopadhyay et al., 2010). Decreased inappentence lead to problems of feed and water intake, whilst protein losses due to gastrointestinal damage diminishes availabilities for growth. These problems combination caused impaired amino acids and minerals metabolism with end up in reduced carcass quality. Additionally, delayed maturity for reproduction and extended calving interval lower milk production can be observed in consequence (Charlier et al., 2009; Parkins and Holmes, 1989). The costs with frequent usage of anti-parasitic drugs, the poor feed conversation rates, the reduction of reproductive and/or productive performances, together with the possibility of drug resistance due to indiscriminate treatments with anti-parasitic drugs, represent some of the factors contributing to the reduced efficacy in cattle production. Indonesia has a high demand of meat in order to fulfill 300 million people needs. Nowadays, self-sufficient production of cattle meat in Indonesia is not possible since meat production is below the national demands, especially due to animal health status and some managerial problems, together with losses in productivity (MoARI, 2011). Therefore, meat has to be imported from abroad since years (MoARI, 2015) implicating a high price of meat that urge the Indonesian government to launch meat selfsufficiency programs (MoARI, 2010). Indonesian government planned to increase population of indigenous, local and commercial breed cattle through several strategic plans i.e.,: push live carcass weight from 150 to $176 \mathrm{kgs}$, weaning rate from 24 to $30 \%$ and calving interval from 21 months to 16-18 months (MoARI, 2011). As gastrointestinal parasites hamper the efficient production of cattle products (e.g., meat, milk) it is mandatory to 
investigate the prevalence of parasitosis in Indonesian cattle farms in order to improve management and production results. This study aims to describe the prevalence of gastrointestinal parasites commonly found in Central Java, the most populated islands in Indonesia. The data provide baseline knowledge of infection levels in the region and support decision-making for control strategies.

\section{Materials and Methods}

Sample collection was carried out for four months, from March to June 2016. Stool samples were collected directly from rectum and faeces were stored in plastic containers and refrigerated at $4^{\circ} \mathrm{C}$ until the time of examination. Random sampling was performed in several districts of Central Java and Special Region of Yogyakarta provinces i.e.,: Kulon Progo, Gunung Kidul, Bantul, Yogyakarta, Magelang and Boyolali. These sampling sites included $7^{\circ} 47.44$ south latitude and $110^{\circ} 8.24$ eastern longitude ordinates. Cattle breed included in the study correspond to those that are commonly farmed in Central Java.

Flotation technique with saturated $\mathrm{NaCl}$ (Foreyt, 2001; Parfitt and Banks, 1970) method were performed to identify parasitic stages. Morphologic identification of parasite stages followed Soulsby (1965), Levine and Ivens (1970) and Floriao et al.(2016).

\section{Results}

Parasites examination showed $65.93 \%$ of the total 455 cows were infected. Single parasite infection reached $79.33 \%(53 / 300)$ of the animals and the rest presented concomitant infections by two or three or more parasites (Fig. 1). Different types of parasites ova and Eimeria spp. unsporulated oocysts found in the study are shown in Table 1 and Fig. 2. Artificial insemination programs generate several crossbreeds commonly found in traditional farms i.e.,: Ongole-Local Cattle (PO) cross breed, Simmental-PO cross breed, PO-Limousin cross breed and Angus-Brahman cross breed. The number of infected animals according to their breed is represented in Table 2. In most of the cases, parasitic infestation reaches $50 \%$ or more animals in all sampled breeds.

The highest nematode parasite infestation was caused by Strongyle-type eggs which reached $54.00 \%$ of the total infected animals, followed by Strongyloides sp. (4.67\%) and Trichuris sp. (3.67\%). Cestode infestation by Moniezia sp. was $0.88 \%$. Trematode parasite infestation by Fasciola sp. was higher (17.00\%) than Paramphistomum sp infections (4\%). Whilst Eimeria spp. infestation was $15.33 \%$. Identification of Eimeria spp. were performed directly from unsporulated oocysts based in morphological features (Fig. 2). The dominant Eimeria spp. examined was E. bovis, E. auburnensis, E. bukidnonensis, E. canadaensis, E. zurnii and E. cylindrica.
Table 1. Gastrointestinal-parasite eggs/oocyst obtained from cattle in Central Java

\begin{tabular}{lc}
\hline Parasite eggs/oocysts & Infected animals (\%) \\
\hline Paramphistomum $\mathrm{sp}$ & 4.00 \\
Fasciola $\mathrm{sp}$ & 17.00 \\
Strongyle-type & 54.00 \\
Eimeria $\mathrm{sp}$ & 15.50 \\
Moniezia $\mathrm{sp}$ & 0.88 \\
Trichuris $\mathrm{sp}$ & 3.60 \\
Strongyloides $\mathrm{sp}$ & 4.60 \\
\hline
\end{tabular}

Table 2. Breed examined for fecal examination

\begin{tabular}{lcc}
\hline Breed & $\begin{array}{c}\text { Number } \\
\text { examined }\end{array}$ & $\begin{array}{c}\text { Number } \\
\text { positive }\end{array}$ \\
\hline Ongole-Local Cattle (PO) cross breed & 120 & 61 \\
Simmental & 125 & 62 \\
Limousin & 98 & 40 \\
Simmental-PO cross breed & 74 & 41 \\
PO-Limousin cross breed & 23 & 12 \\
Friesian Holstein (FH) & 7 & 4 \\
Angus & 2 & 1 \\
Brahman & 1 & 1 \\
Angus-Brahman cross breed & 1 & 0 \\
Bali & 4 & 4 \\
\hline
\end{tabular}

\section{Discussion}

With this study, we demonstrated highly parasitic infections in cattle in the region of Central Java, the most populated island in Indonesia. Our findings are consistent with other reports from various tropicaldeveloping countries (Nginyi et al., 2001; Mejia et al., 2003; Tan et al., 2014; Hussain et al., 2014). This study show that infections with nematodes was common and especially Strongyles were the most frequent compared with other types of worms.

Different risk factors have been described to influence the outcome of parasitic infections in cattle. One of the most important risk factors contributing to high parasitism of tropical areas is likely the constant high temperatures, which favors development of parasitic stages. Temperature range of Central Java is around 20$27^{\circ} \mathrm{C}$ with little variation throughout the year as it has equatorial climate. In the rainfall season the humidity increases $70-85 \%$. For example for Haemonchus contortus high rainfall is related to a proportional increase of the number of migrated L3 from fecal material to pasture (Santos et al., 2012; Silva et al., 2008).

Besides temperature, the management system of the farms also significantly contributes to a higher prevalence of gastrointestinal parasitism (Kumar et al., 2013; Barger, 1997). Almost all animals sampled in this investigation were reared under traditional methods of husbandry in smallholder farmer systems. Animals were fed with forage, i.e., rice straws, from the same land. In Central Java, the forage rotation is difficult to perform due to narrowing land for residential, road and government purposes, complicating parasites control measures (Stuedemann et al., 2004; Larsson et al., 2007). Moreover, feeding imbalance 
composition leads to malnutrition, which contributes to the lack of immunity against parasites (Hughes and Kelly,
2006). This risk factor may also increase animal susceptibility toward mixed infections (Fig. 1).



Fig. 1. Distribution of mixed and co infection of parasites among cattle in Central Java
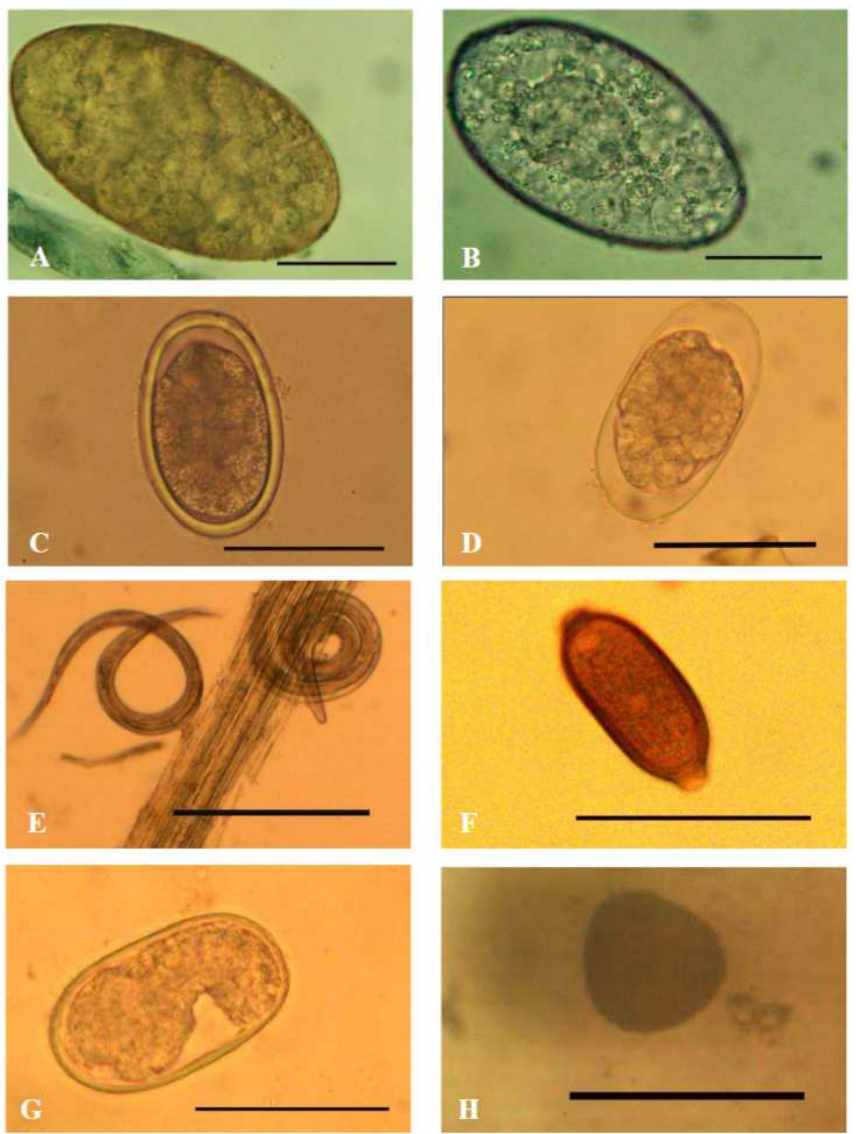

Fig. 2. Micrograph of gastrointestinal parasites eggs examined in cattle of Central Java. A. Fasciola sp. B. Paramphistomum sp. C.D. Strongyle-type egg. E. Fecal larva. F. Trichuris sp. G. Strongyloides sp. H. Moniezia sp. Scale bars are $50 \mu \mathrm{m}$ 

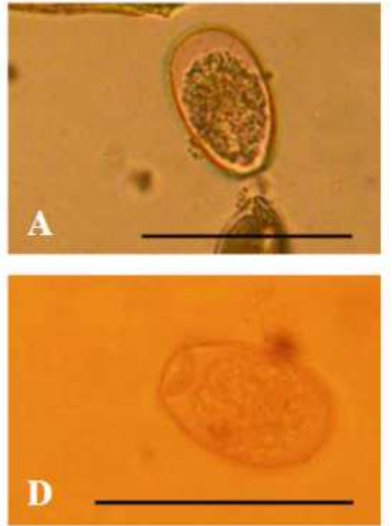
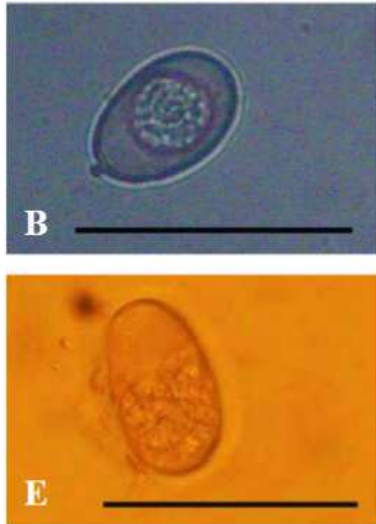
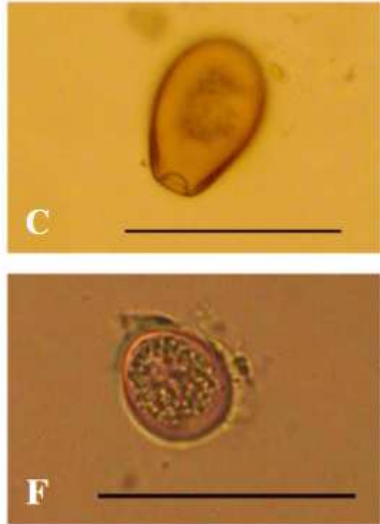

Fig. 3. Unsporulated oocysts obtained from cattle in Central Java. Scale bars are $50 \mu \mathrm{m}$. A Eimeria auburnensis. B. E. bovis. C. E. bukidnonensis. D. E. canadensis. E. E. cylindrica. F. E. zurnii
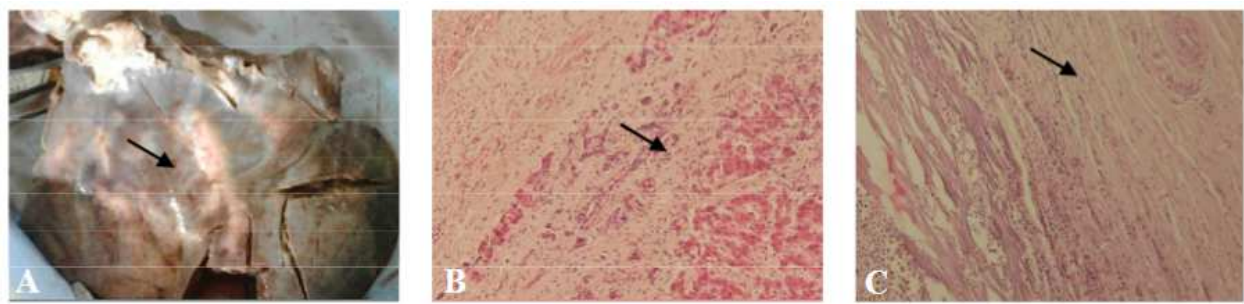

Fig. 4. A. Bovine liver of severe fasciolosis. B. and C. Histopathologic change of A. B and C are in 200X magnification

For trematode infestation, Fasciola sp. was the most prevalent parasite followed by Paramphistomum sp. This result confirms fasciolosis in cattle often found during Eid al-Adha when people sacrifice cattle for human consumptions (personal observations). Since the majority of Java residents are Moslem, thousands of cattle are slaughtered in one to three days, in order to fulfill religious festivities. Due to the zoonotic potential of fasciolosis, particularly at this time of the year, several infected livers (Fig. 4A) have to be discarded from human food chain to prevent human consumption. The implication of fasciolosis is displacement of hepatocytes with fibrocytes (arrows in Fig. 4B) and lead to development of connective tissue in almost all liver areas (arrows in Fig. 4C). Intensive guidance from institutions is a compulsory for public health importance during this event.

Clinical coccidiosis was rarely found in this investigation. However, subclinical coccidial infection was probable due to infections of one or more species of Eimeria (Fig. 3). This also indicates that the infestation with coccidia can still occur in adult cattle in accordance with previous reports (Sudhakara Reddy et al., 2015). Eimeria bovis and E. zuernii were reported here and they are noted as the most pathogenic species of Eimeria affecting cattle. Even low infectious doses of E. bovis oocysts $\left(10^{4}\right)$ and E. zuernii $\left(10^{5}\right)$ result in severe haemorrhagic enteritis with weight losses, dehydration or death of heavily infected animals (Mundt et al., 2005; Hermosilla et al., 1999).

Our study reveals the importance of gastrointestinal parasitism in cattle in Central Java. To overcome the negative impact of such parasitic diseases, efficient control measures should be implemented. Administration of the same anthelminthic substances for long time without proper evaluation may lead to considerable costs for traditional farms and raise the possibility of resistance to the substances (Mejia et al., 2003; Muniz-Lagunes et al., 2015). In addition, gastrointestinal diseases has an impact in animal health status that usually implicates a reduction in animals performance, reducing for example daily weight gains, which hampers government's efforts in the national meat self-sufficiency program.

\section{Conclusion}

This study showed a high rate of gastrointestinal parasitic infections in traditional farms in Central Java. These results indicate the need to establish efficient control measures that improve animal health and performance by lowering the gastrointestinal parasitism of cattle.

\section{Acknowledgement}

The research was funded by grants competence number 015 / SP2H / LT / DRPM / II / 2016 the Ministry 
of Research, Technology and Higher Education of the Republic of Indonesia.

\section{Author's Contribution}

Penny Humaidah Hamid: Designeddid the research and wrote the manuscript.

Yuli Purwandari Kristianingrum and Joko Prastowo: Did the research.

Liliana Machado Ribeiro da Silva: Analyze result and wrote the manuscript. All authors approve the manuscript.

\section{Competing Interest}

Authors declare that they have no competing interest.

\section{Reference}

Bandyopadhyay, S., S. Mandal, K.K. Datta, P. Devi and S. De et al., 2010. Economic analysis of risk of gastrointestinal parasitic infection in cattle in North Eastern States of India. Trop. Anim. Health Prod., 42: 1481-1486. DOI: $10.1007 / \mathrm{s} 11250-010-9582-6$

Barger, I., 1997. Control by management. Vet. Parasitol., 72: 500-496.

Charlier, J., J. Hoglund, G. von Samson-Himmelstjerna, P. Dorny and J. Vercruysse, 2009. Gastrointestinal nematode infections in adult dairy cattle: Impact on production, diagnosis and control. Vet. Parasitol., 164: 70-79. DOI: 10.1016/j.vetpar.2009.04.012

Corwin, R.M., 1997. Economics of gastrointestinal parasitism of cattle. Vet. Parasitol., 72: 457-460. DOI: 10.1016/S0304-4017(97)00110-6

Floriao, M.M., B. Lopes Bdo, B.P. Berto and C.W. Lopes, 2016. New approaches for morphological diagnosis of bovine Eimeria species: A study on a subtropical organic dairy farm in Brazil. Trop. Anim. Health Prod., 48: 577-584. DOI: $10.1007 / \mathrm{s} 11250-016-0998-5$

Foreyt, B., 2001. Veterinary Parasitology Reference Manual. 5th Edn. Iowa State University Press, Ames, Iowa.

Grisi, L., R.C. Leite, J.R. Martins, A.T. Barros and R. Andreotti et al., 2014. Reassessment of the potential economic impact of cattle parasites in Brazil. Rev. Bras Parasitol. Vet., 23: 150-156. DOI: $10.1590 / \mathrm{S} 1984-29612014042$

Hermosilla, C., H.J. Burger and H. Zahner, 1999. T cell responses in calves to a primary Eimeria bovis infection: Phenotypical and functional changes. Vet. Parasitol., 84: 49-64. DOI: $10.1016 / \mathrm{S} 0304-4017(99) 00075-8$

Hughes, S. and P. Kelly, 2006. Interactions of malnutrition and immune impairment, with specific reference to immunity against parasites. Parasite Immunol., 28: 577-588. DOI: 10.1111/j.1365-3024.2006.00897.x
Hussain, T., K. Periasamy, A. Nadeem, M.E. Babar and R. Pichler et al., 2014. Sympatric species distribution, genetic diversity and population structure of Haemonchus isolates from domestic ruminants in Pakistan. Vet. Parasitol., 206: 188-199. DOI: 10.1016/j.vetpar.2014.10.026

Kumar, N., T.K. Rao, A. Varghese and V.S. Rathor, 2013. Internal parasite management in grazing livestock. J. Parasit. Dis., 37: 151-157.

DOI: $10.1007 / \mathrm{s} 12639-012-0215-\mathrm{z}$

Larsson, A., S.O. Dimander, A. Rydzik, A. Uggla and P.J. Waller et al., 2007. A 3-year field evaluation of pasture rotation and supplementary feeding to control parasite infection in first-season grazing cattledynamics of pasture infectivity. Vet. Parasitol., 145: 129-137. DOI: 10.1016/j.vetpar.2006.12.005

Levine, N.D. and V. Ivens, 1970. The Coccidian Parasites (Protozoa, Sporozoa) of Ruminants. 1st Edn., University of Illinois Press, Urbana, pp: 278.

McLeod, R.S., 1995. Costs of major parasites to the Australian livestock industries. Int. J. Parasitol., 25: 1363-1367. DOI: 10.1016/0020-7519(95)00071-9

Mejia, M.E., B.M. Fernandez Igartua, E.E. Schmidt and J. Cabaret, 2003. Multispecies and multiple anthelmintic resistance on cattle nematodes in a farm in Argentina: The beginning of high resistance? Vet. Res., 34: 461-467. DOI: 10.1051/vetres:2003018

MoARI, 2010. Pedoman umum program swasembada daging sapi tahun 2014. Ministry of Agriculture Republic Indonesia.

MoARI, 2011. Rencana strategis dan kebijakan pembangunan peternakan nasional menuju swasembada daging. Ministry of Agriculture Republic Indonesia.

MoARI, 2015. Livestock and animal health statistic. Ministry of Agriculture Republic Indonesia.

Mundt, H.C., B. Bangoura, H. Mengel, J. Keidel and A. Daugschies, 2005. Control of clinical coccidiosis of calves due to Eimeria bovis and Eimeria zuernii with toltrazuril under field conditions. Parasitol. Res., 97: S134-S142. DOI: 10.1007/s00436-005-1457-9

Muniz-Lagunes, A., R. Gonzalez-Garduno, M.E. Lopez-Arellano, R. Ramirez-Valverde and A. Ruiz-Flores et al., 2015. Anthelmintic resistance in gastrointestinal nematodes from grazing beef cattle in Campeche State, Mexico. Trop. Anim. Health Prod., 47: 1049-1054. DOI: $10.1007 / \mathrm{s} 11250-015-0826-3$

Nginyi, J.M., J.L. Duncan, D.J. Mellor, M.J. Stear and S.W. Wanyangu et al., 2001. Epidemiology of parasitic gastrointestinal nematode infections of ruminants on smallholder farms in central Kenya. Res. Vet. Sci., 70: 33-39. DOI: $10.1053 /$ rvsc. 2000.0438

Parfitt, J.W. and A.W. Banks, 1970. A method for counting Fasciola eggs in cattle faeces in the field. Vet. Rec., 87: 180-182. DOI: 10.1136/vr.87.7.180 
Parkins, J.J. and P.H. Holmes, 1989. Effects of gastrointestinal helminth parasites on ruminant nutrition. Nutr. Res. Rev., 2: 227-246.

DOI: $10.1079 /$ NRR19890016

Santos, M.C., B.F. Silva and A.F. Amarante, 2012. Environmental factors influencing the transmission of Haemonchus contortus. Vet. Parasitol., 188: 277-284. DOI: 10.1016/j.vetpar.2012.03.056

Silva, B.F., M.R. Amarante, S.M. Kadri, J.R. CarrijoMauad and A.F. Amarante, 2008. Vertical migration of Haemonchus contortus third stage larvae on Brachiaria decumbens grass. Vet. Parasitol., 158: 85-92. DOI: 10.1016/j.vetpar.2008.08.009

Soulsby, E.J.L., 1965. Helminths. Blackwell Scientific Publications, Oxford.
Stuedemann, J.A., R.M. Kaplan, H. Ciordia, A.J. Franzluebbers and T.B. Stewart et al., 2004. Bermudagrass management in the Southern Piedmont USA: V: Gastrointestinal parasite control in cattle. Vet. Parasitol., 126: 375-385. DOI: 10.1016/j.vetpar.2004.09.007

Sudhakara Reddy, B., S. Sivajothi and V.C. Rayulu, 2015. Clinical coccidiosis in adult cattle. J. Parasit. Dis., 39: 557-559. DOI: 10.1007/s12639-013-0395-1

Tan, T.K., C. Panchadcharam, V.L. Low, S.C. Lee and R. Ngui et al., 2014. Co-infection of Haemonchus contortus and Trichostrongylus spp. among livestock in Malaysia as revealed by amplification and sequencing of the internal transcribed spacer II DNA region. BMC Vet. Res., 10: 38-38. DOI: $10.1186 / 1746-6148-10-38$ 